\title{
STUDENT PERCEPTIONS OF THE USE OF STUDENT-GENERATED VIDEO IN ONLINE DICUSSIONS AS A MECHANISM TO ESTABLISH SOCIAL PRESENCE FOR NON-TRADITIONAL STUDENTS: A CASE STUDY
}

\author{
Richard Pinsk, Strayer University, richard.pinsk@strayer.edu \\ Michael J. Curran, Strayer University, michael.curran@strayer.edu \\ Ryan Poirier, Strayer University, ryan.poirier@strayer.edu \\ Gordon Coulson, Strayer University, gordon.coulson@strayer.edu
}

\begin{abstract}
This report presents a case study of five online non-traditional undergraduate students who used self-created video discussion posts for a class. The study attempted to discover the influence that this type of action had on establishing social presence in online courses, which is often described as one of the critical factors in student success and satisfaction with online classes. In this study students indicated that they felt they had established a strong social presence in the online class as a result of using self-created discussion videos. Additionally, several themes emerged in regard to using self-created discussion videos; these major themes were course engagement, projection of self, and connections to other classmates and the professor. Sub-themes were present in each of the major themes as well. These included time considerations, technical issues, and interest in innovation. Overall, the use of self-created student discussion video posts did seem to create a sense of social presence for these participants in their online class.
\end{abstract}

Keywords: non-traditional students, student-generated video, online discussions, social presence, qualitative study, Kaltura video, Community of Inquiry

\section{INTRODUCTION}

The rapid development of online education has spurred a number of research studies on factors that contribute to a successful online program [2]. Among factors that consistently are cited as significant, the issue of 'presence' in an online environment is often cited as a critical success factor $[30,32,33,38]$. While there are several components of presence, of particular interest to this study was the creation of social presence. This type of presence, while easily achieved by both faculty and students in traditional campus-based classes, is often considered one of the more difficult concepts to manifest in online classes [4,9]. Students often cite this as a cause for dissatisfaction with online courses and a reason for a lack of 'connection' to the instructor and to other classmates [11]. Some research suggests that the use of video can be used as a way to increase student satisfaction, engagement with online courses, and overall student success $[19,20]$.

Social presence is generally defined as the ability to project 'self' into an asynchronous environment. Much of the pioneering work in this area was developed using the 'Community of Inquiry (CoI)' framework developed by Garrison et al $[22,23,24,25]$. This type of presence has been found to positively relate to student satisfaction with online courses and, to a lesser degree, with performance outcomes. Community of Inquiry research also indicates that social presence can influence cognitive presence as well and may lead to enhanced learning [5,6,27]. Defining the exact nature of social presence has been a challenging issue for researchers and its relationship to asynchronous learning environments is a consistently challenging area [41,56]. However, much of the current research suggests that using student and faculty created videos in discussions may have an impact on increasing social presence $[48,50]$.

The university that served as the vehicle for this study had established that student engagement was a key driver of overall student success and had recently adopted a mechanism to increase the use of instructor-generated video content in online courses. The university uses Blackboard as the sole platform for online courses and recently had integrated Kaltura-brand video tools to the online learning environment that more easily allowed faculty to create videos for instructional purposes. Some faculty at this university had used YouTube in the past to create video content. While this was generally favorably reviewed by students one of the drawbacks was time. YouTube-created videos usually required a minimum of 24 hours before they could successfully be uploaded and viewable by students. Additionally, there were security issues since oftentimes the videos were 'public'. Kaltura successfully resolved all of these issues and therefore they were well suited to be used in discussion posts, one of the most 


\section{Issues in Information Systems \\ Volume 15, Issue I, pp. 267-276, 2014}

important areas in an online class for teacher-student interactions. The university made a concerted effort to encourage the use of this technology.

One instructor had taken on a leadership role in this area and was extensively using video content in a number of innovative ways. These included video lectures, weekly messages, and most significantly discussion posts. This instructor had been using this format for several academic terms with success and the received feedback from several students in one class that they not only liked this innovative approach to discussions, but wished that they too could participate with video responses. While students had this capacity with the introduction of Kaltura, it was not widely used by students at this time. Since social presence is a key success factor in online courses, a qualitative study was then conducted with a number of students who had expressed interest in using this technology in online discussions. The research question was, "To what degree did the use of student-generated video discussion posts create social presence for those students?" A case study approach was adopted and students that used this format for discussions were interviewed and the data analyzed in an effort to answer this key research question.

\section{LITERATURE REVIEW}

Development of online education and its rapid expansion has been well documented $[2,13]$. The primary mechanism for student interaction in most asynchronous learning environments is discussion posting $[44,47,60]$. There has been substantive research indicating that this format has, at best, achieved mixed results in generating interaction $[10,26,45]$. However, social presence goes beyond simple interaction and establishes students' perception of 'self' into online learning environments. Much of the research indicated that 'social presence' had a relationship with overall satisfaction and success for students $[14,17,31,35,36]$. Several studies indicate that there are significant challenges to developing social presence within an online environment $[3,7,15,34]$. There is also research that indicates that students that develop strong social presence in online courses have higher rates of retention and grade outcomes $[39,46]$. Some studies also suggest that one of the main attractions for some people to take online courses is that they have introverted personalities and may not value the type of social presence that is common in campusbased classes $[8,49,52]$. Some studies also indicate that social presence may have a cultural component and that this concept may be perceived differently based on cultural dimensions $[42,57,58,59]$.

There has been considerable study on the emergence of social presence within asynchronous learning environments [51,54]. Several studies have emphasized that the use of discussions in online courses are a primary venue for the development of social presence $[12,53]$. While most studies have examined how students use text to project 'self' into discussions and therefore begin to create social presence, the use of video has only recently become a source of study. The power of video to project aspects of self, including physical appearance in the class, tone of voice, body language and other factors has been seen as an important source of projection of self $[21,28,37]$. The use of video in online discussions has also had an influence on overall student satisfaction with online courses which may in part be manifested in increased social presence by both faculty and staff within the course $[16,29,40]$. However, most research on this topic has been with traditional college students. With the growing number of non-traditional students and the expansion of online education, the relationship between these variables remains a viable and important topic in higher education.

\section{RESEARCH METHODOLOGY}

\section{Rationale for using the case study method}

A case study methodology was adopted for this project. A case study is an effective qualitative technique when the researcher has clearly identifiable cases within established boundaries and seeks to provide a greater in-depth understanding of a phenomenon, and allows for the emergence of sometimes subtle themes that are consistent throughout the experience $[18,43]$. In this case, the boundaries are very clear and narrowly defined: the experiences of five college students as they transitioned from using traditional type-based online discussions to a studentgenerated video format. This situation was therefore appropriate for a case study methodology. Another reason for using this approach was to see if factors consistent with the development of social presence were experienced by a majority of the participants. 


\section{Participants}

The five students that participated in this study were selected based on a convenience sample. The professor for the course extensively used video for many aspects of the course, including announcements, quiz reviews, and discussions. Several students had expressed an interest in this method of interaction through emails or discussion posts. So, during week 3 of the class which ran for 11 total weeks, the professor posted an announcement that anyone interested in learning how to post to discussions using video rather than traditional typing should contact him. Nine students (from a class population of 25) emailed the professor that they would be interested in learning how to post using video. The professor conducted a tutorial in how to access Kaltura's video production module within the online course shell and how to create and post video discussions. The professor also asked each of the participants if they would be willing to be interviewed at the end of the course to discuss their perceptions on the use of this technology. After these sessions, seven agreed to participate. Of the seven, five actually produced at least 3 video discussion responses and were interviewed for this study. A breakdown of the number and length of the video posts is presented in Table 1:

Table 1: Number and Length of Self-produced Discussion Post Videos

\begin{tabular}{|l|c|c|}
\hline Participant & $\begin{array}{c}\text { Total Number of Video Discussion } \\
\text { Produced }\end{array}$ & Average length of Post \\
\hline Victoria & 23 & $2: 45$ \\
\hline Braelin & 15 & $2: 10$ \\
\hline Robert & 9 & $2: 54$ \\
\hline Dale & 9 & $1: 38$ \\
\hline Spencer & 7 & $2: 04$ \\
\hline
\end{tabular}

Victoria (all names used are pseudonyms) was a 29 year old female. She was a single mother of two small children and currently worked full-time as a clerical at a small firm. She was in her second year at the university and was pursuing a Bachelor's Degree in Marketing. All her previous course experience had been in an online format due to her work and child care schedules. She described herself as "outgoing" and "someone who really likes meeting and working with people." She also assessed her computer and internet skills as "average". She also evaluated herself as a "solid A student."

Braelin was a 25 year old female. She was married with one child and currently is a stay at home mother. She was in her first year at the university and was working on a Bachelor's Degree in Business Administration. She had taken two other classes at the university, both online. She described herself as "pretty quiet and really into just staying at home and taking care of my son." She also stated, "I don't really like a lot of face-to-face time in classes, so I think the online stuff is just great for me." She considered her level of computer literacy to be "very good" and assessed her academic standing in this manner, "If I could devote all my time to school I would probably do a lot better. But raising a child is really my first priority, so sometimes my classes kind of take a back seat to that."

Robert was a 46 year old male. He was divorced and currently worked full-time in a manufacturing industry. He had been in the armed services for over ten years prior to attending the university. He had three children who lived with their mother and he was in his first year with the university and was pursuing a Bachelor's Degree in Information Systems. He described himself as "your typical military guy, if you tell me to do something, I'll get it done". He had taken only one campus-based class which he said he enjoyed a lot more than the online classes he had taken. He assessed his computer and internet skills as "outstanding" and considered himself to be a "B student in courses that aren't in my major and an A student in my major courses."

Dale was a 27-year-old male. He was single with no children. He worked part-time as a telemarketer and was in his first semester at the university working on a Bachelor's Degree in Management. He described his personality as "usually more of an introvert, that's why I like online." He had taken no previous courses at the university, but was currently taking one other online class (not required for his major), which he described as "a nightmarish experience". He considered his computer skills to be "excellent" and stated that, "While I was not the greatest high school student, I think that was because I was not really mature enough or focused enough. Now I have my priorities in order and really do expect to do A level work from here on." 


\section{Issues in Information Systems \\ Volume 15, Issue I, pp. 267-276, 2014}

Spencer was a 30 year old male. He was married with two children. He worked full-time in a service industry and stated, "I need this degree for a promotion at work, and so the sooner I get done the better." He was pursuing a Bachelor's Degree in Accounting. He described himself as, "very outgoing and pretty easy to talk to. I'm not going to lie, I probably don't spend much time on the online discussion, I usually just do what I need to so I can get my points." This was his second year with the university and the second time he had taken this class (after having failed it the previous semester). He had taken an almost even balance between online and campus-based courses and stated that he strongly preferred campus-based because, "I just learn better in them, I need that face to face interaction and I need to be able to ask questions." He described his computer skills as "overall pretty strong" and said, "As a student, well, not really focused on grades, I just need to get C's because I get reimbursed as long as I get at least a C."

\section{Data Collection}

At the conclusion of the term interviews were held with each participant. Each interview followed a semi-structured format designed to capture as much of the 'experience' of the participant as possible. An interview protocol was developed and used during this phase of the study. The protocol was reviewed by two subject matter experts in order to establish the validity of the questions used in the process. Interviews ranged from 60 to 90 minutes and were conducted via telephone, since the participants were part of an online class and were geographically dispersed. Each interview was recorded and then transcribed. In order to assure maximum reliability in the data, each interview was transcribed by two different researchers and then the transcripts were compared to assure accuracy of the data. Case studies often also include the use of archival data or physical artifacts in addition to personal interviews. In this case, data collected by the university on 'student engagement' was also reviewed $[18,43]$.

\section{Data Analysis}

After the interviews were transcribed, they were initially reviewed. This within-case analysis provided initial familiarity with the data. The data was then coded for themes. Two separate coders were used and the results compared to ensure consistency and reliability. One of the major challenges with this case study was the establishment of epoche, a process by which the researcher excludes any personal bias or judgment when reviewing the data $[18,43]$. This was especially challenging since one of the researchers was the professor for the class and had a deeper understanding of the student participants. This necessitated the use of the second coder. Then, crosscase analysis was used to facilitate insights beyond preliminary impressions. Themes began to emerge as the data was coded and analyzed. Enumeration and categorization of the data was also performed at this stage [18].

\section{RESULTS}

Three critical components emerged as important elements among the participants regarding the establishment of social presence within the online experience in this class: course engagement, projection of self, and connection to other members of the class and the instructor. These factors were consistent with the literature on the development of this phenomenon $[9,15,22,23,24,25]$. Further investigation revealed that within each of these major thematic areas, three sub-factors were present, time considerations, technical issues, and interest in being innovative. Each of these sub-factors influenced, to varying degrees, the major themes that emerged.

Course Engagement - Consistently cited as one of the most important factors in success for online students is their ability to become engaged in the learning environment $[10,32,53]$. Since much of the asynchronous learning environment is self-paced and there is virtually no face to face real time interaction, a sense of isolation can often inhibit student success $[15,19]$. For these participants the use of video in discussions increased their engagement in the course. Key phrases and words that were used to code for class engagement included, "really feel a part of the class", "highly involved", "Highly engaged", "enjoy logging in a lot and participating."

Time Considerations: Time issues were mentioned as significant factors by each of the participants in regard to course engagement. Four of the five participants were evaluated as 'highly engaged' according to metrics used by the university to measure involvement in online courses, while the fifth was evaluated as 'moderately' engaged. Victoria, a participant who created the largest number of videos, commented, "They took a lot of time to make, especially at first, because I kept re-doing them to make them perfect. I hardly ever do that with typed posts." Robert stated, "It takes at least twice as long to make a video post because you have to know what you're going to 


\section{Issues in Information Systems \\ Volume 15, Issue I, pp. 267-276, 2014}

say before you start recording. When you type you can just stop and start as needed." Dale stated, "I know I spent way more time on this class than the other class I was taking. I think that's because I was really into making these video posts." Braelin mentioned, "Although I knew this was taking a lot more time than regular typing did, I enjoyed it more because it really felt like I was actually in class. I mean that's what you do in a class, you talk, right?" While time was a significant issue for each of the students, three mentioned that the time issue seemed less as the semester went on. As far as establishing social presence as part of engagement, four of the students mentioned how creating video discussion posts actually caused them to feel as if the time was less of a significant issue and was in fact not a hindrance to creating video discussion posts. Spencer commented, "I liked the class, in large part because of my and the professor's videos, I felt connected to the class in ways I never did in any other online class. Sure, it took time, but it was well worth it and once I got used to it, it took less time." Clearly students recognized early on that this type of participation was more labor intensive than traditional discussion methods. However, all participants viewed the time spent as a positive in relation to their overall engagement with the course.

Technical Issues: Three of the participants discussed how technical issues impacted them both positively and negatively in establishing a presence using self-created discussion videos. Of particular concern for these participants (expressed by all three) was lack of experience with the Kaltura technology and apprehension about appearing inept in its use. Dale mentioned, "At first I was fearful that if I wasn't able to do decent videos that I might not participate very much." This sentiment was echoed by other participants. However, their experience using this technology soon created the opposite perception; Victoria stated, "It was really easy to use the video apparatus once you just did it a few times. I actually thought it was cool showing off how good I was at it and that made me respond with even more videos." While technical issues may have been an inhibiting factor early on, the relatively easy to use technology soon become a positive for students engaging in the online class.

Interest in Innovation: Interest in innovation was cited by four of the five participants as a factor in increasing their engagement in this class. Spencer noted, "The video technology, quite honestly, was just really cool. It was new and really provided for a fun class experience. It really felt like I was on the cutting edge of something that a lot more classes should adopt, and being in at the beginning made me want to really be more involved." This was also a theme for Braelin, "I always like new and interesting things and this technology was amazing. I even found myself recording and doing them over and liked that I was doing something almost no one else in the class was." While online courses are generally often using new and innovative approaches to increase engagement, this technology appeared to have a positive impact on students desire to be active and involved in the online course.

Projection of Self - Among the most critical factors in developing a sense of social presence is the idea of a sense of 'self' within the context of the asynchronous learning environment $[5,7,15,19,24,27,41]$. This issue emerged as the strongest theme for these participants. Key words and phrases that were used to code for projection of self in the class included, "I actually felt like I was in real class", "felt personally in the class", "I could see and hear myself and it felt real", and "personally involved".

Time Considerations: All of the participants mentioned that they spend considerably more time in this course than in other online courses they were currently taking or had previously taken. In each case, the time consideration was a direct reflection of the desire to have a social 'presence' in the class. Several comments were exemplars of this consideration. Robert stated, "I spent a heck of a lot more time preparing what to say. When you type, it was always off the top of my head because who cares if it's really that good. But when you are actually saying it in a video, it's like you're really there, and that matters." This was further echoed by Victoria, "I really felt like I was actually 'in' the class. People could actually see and hear me and it felt so much like a physical class. That was really what made me want to devote more time to the class; I wanted to make an impression." Braelin also stated, "at first, it seemed like a lot of prep time before I would record and I did not think I would like that, but when you see yourself in the video and you know others are watching and listening to you I think I was willing to devote time to make it better because it felt like I was physically in the class." Dale mentioned another interesting issue, "You know what I thought was strange? I actually took time to comb my hair and put on a nice shirt. It was like I was actually there and I wanted to appear as professional as I could. I rehearsed these and actually wound up rerecording a few of them. I knew this would take a lot of time, but I wanted everyone to have a positive impression of me as a person and as a scholar." For each of these participants it appears that because they perceived a more physical 'presence' in the class that they were very accepting of devoting greater time to both the content of their discussion posts and their own appearance. 


\section{Issues in Information Systems \\ Volume 15, Issue I, pp. 267-276, 2014}

Technical Issues: Several participants discussed some technical concerns and issues that related to their projection of self. Spencer noted that, "At first I just thought I would do one and be done with it, but I was so impressed with how easy the system was to work with that I continued to do more. The technology was so much easier than I thought it would be." Robert also commented, "I always wanted to make sure that the sound and picture quality were perfect because after all, it was me they were looking at and I did not want to seem like either I could not use the technology, or worse, I would look foolish." Dale echoed this issue, "Since I knew that people were looking at me, I always had to be sure I was groomed well, had an appropriate background and then I would view it to make sure it looked good. Because sometimes the technology makes you look different than you really are." Again, it appears that for these participants, the idea of projecting themselves physically into the asynchronous learning environment provided an impetus to work with and overcome any technical concerns.

Interest in Innovation: All of the participants expressed some appreciation for the novelty of this approach to online discussions. Spencer stated, "One of the coolest parts of this was the newness of it all. I had never done anything like this in any other class and I was able to be one of the first people to actually feel like I was in a physical classroom." Robert also stated, "I think this really represents the future of online discussions and it was cool to feel like I was actually part of this innovation." Perhaps this issue was best summarized by Victoria, "Physically being in the class was an awesome feeling, and I really thought that was the coolest part. But being one of the few that did it made it more unique and innovative for me. I like to be a leader." This was a telling statement because she did not say it was 'like' physically being in the class. She stated that she 'was' physically present. The use of student-generated video worked so well for this participant that she transcended the gap of isolation described in the problem statement earlier. The concept of developing social presence in online discussions as a unique and innovative part of the online experience was a compelling issue for each of these participants.

Connection to Other Class Members and the Professor - Engagement and connection to class members are consistently cited as sources of satisfaction in online courses and the development of personal connections within an asynchronous learning environment is also considered a key component in establishing a social presence $[7,10,29]$. This theme emerged among virtually all participants. Key words and phrases that were used to code for this theme included, "bonded with other classmates", "connected", "felt like we belonged in our own separate group", "we were actually working with the professor", and "team".

Time Considerations: All of the participants expressed spending considerable time making video discussion responses. However, that concern was ameliorated by a stronger connection to the class. Robert expressed this issue thusly; "I've never felt more connected to an online class. I could actually talk to students and the professor. It was absolutely worth the time and effort. You spend so much time in the classes feeling alone and isolated and I actually felt like I was part of this class, especially when I watched the other students' videos." This was also echoed by Braelin, "We could see each other, hear their voices, and see their body language. That was so valuable that it made the extra time spent really worthwhile." It was evident from the research that each of the participants believed that although additional time was mandated to successfully use video discussion posts that the sense of belonging and connection made the effort worthwhile.

Technical Issues: One of the interesting issues was the degree to which technical issues served as a bonding issue for these students. Four of the students expressed that they had 'frequent' contact with each other via both email and phone in order to improve the quality of their video discussion posts. Spencer's response served as an exemplar of this, "What was amazing was that after a week or so we kind of all started talking to each other about webcams and sound glitches and other topics. We would text or message each other so that we could always put our best foot forward on these posts. We were like our own little sub-group." The sense of being in a group also served to enhance the students overall satisfaction with the course and the video experience.

Interest in Innovation: This bonding experience was also expressed regarding the students' interest in innovation. Victoria stated, "We were leaders and innovators. I really think a lot of the other students were a bit envious of us since we sort of dominated the discussions." There was a slight increase in the number of student responses to video posts compared to student responses to typed posts. Robert also stated, "We were our own little club of innovators, we were doing something new and unique and I think it really brought us together and I even think we had a stronger bond with the professor as a result of this." The innovative nature of this technology and the fact that it was such a small group enhanced the cohesiveness of the participants. 


\section{CONCLUSIONS}

The results of the study indicated that for these participants using student-generated video posts in online discussions enhanced their perceptions of physically being in the class and helped them to achieve a sense of social presence. When asked to rate how strongly they felt they were 'actually in' the class, each of the participants indicated that that they felt "fully involved", or "actually felt like my personality was showing through in the video posts." Each participant also indicated that they felt more 'present' in this class than in any other online course they were taking at that time. While defining this term can often be challenging, there seemed to be a strong relationship between using video discussion post factors associated with developing social presence, particularly course engagement and projection of self.

None of the demographic factors, including personality type, academic standing, and familiarity with technology, age or gender appeared to have any influence on the perceptions that these participants had regarding the use of student-generated video content in creating a social presence. The use of video did appear to be relatively equally valuable to each of the participants [11]. Since social presence is considered an important attribute in student success in online courses, any factor that can influence the development of social presence should be considered an important area of study in higher education. While some research indicates that increased social presence in asynchronous learning environments does relate to higher grade outcomes, and each participant in the study indicated that they felt they "learned a lot more in this class" than in other classes, there was not a statistical significance in grade difference between the video-producing students and the overall class population. The small sample size of the video-producing group may account for this and opens an additional area for research. The continued development of video technology in asynchronous learning environments combined with increasing sophistication on the part of users presents some potentially significant opportunities to improve student outcomes and satisfaction in regard to discussions in online courses.

\section{FUTURE RESEARCH}

This study demonstrates that there may be some significant potential in using video for online discussions as a means to establishing social presence for students. The use of video in many aspects of online learning environments represents a new and potentially vibrant area for study. Since different demographic groups may react differently to this type of technology, further research is needed. Student-generated video content may work very well for some students, but for those with language issues or those with issues of social adjustment, this technology may represent a hindrance to success if other students continue to use this technology. Further research in this area can establish appropriate parameters for the use of this technology. Another interesting area for study would be comparing the occurrence of social presence between students who used student-generated video content in discussions and those that did not. While it does appear that a degree of social presence emerged from those that created video discussion posts the effect of video on that phenomenon could better be determined using a comparison study.

\section{LIMITATIONS OF THE STUDY}

While the results of the study do indicate that these participants did experience the development of social presence and they had a positive experience using this technology, the results of this study should be viewed with caution. The sample size was small and non-traditional students do not readily fit into neat categories from which large extrapolations of results can be applied. Additionally, since all data was taken from only one class, the role of the professor in influencing the perceptions of these students might also have been a factor. Within these limitations however, the study does contribute to the overall body of knowledge in the field of online education.

\section{REFERENCES}

1. Akyol, Z., \& Garrison, D. R. (2008). The development of a community of inquiry over time in an online course: Understanding the progression and integration of social, cognitive and teaching presence. Journal of Asynchronous Learning Networks, 12(2-3), 3-23.

2. Allen, I. E., \& Seaman, J. (2011). Going the distance: Online education in the United States. Babson Park, MA: Babson Survey Research Group. 


\section{Issues in Information Systems \\ Volume 15, Issue I, pp. 267-276, 2014}

3. Allmendinger, K. (2010). Social presence in synchronous virtual learning situations: The role of nonverbal signals displayed by avatars. Educational Psychology Review, 22(1), 41-56.

4. Anderson, T., Rourke, L., Garrison, D., \& Archer, W. (2001). Assessing teaching presence in a computer conferencing context. Journal of Asynchronous Learning Networks, 5(2).

5. Annand, D. (2011). Social presence within the community of inquiry framework. The International Review of Research in Open and Distance Learning (IRRODL), 12(5), 40-56.

6. Arbaugh, J. B., Cleveland-Innes, M., Diaz, S., Garrison, D. R., Ice, P., Richardson, J. C., Shea, P., \& Swan, K. (2008). Developing a community of inquiry instrument: Testing a measure of the community of inquiry framework using a multi-institutional sample. The Internet and Higher Education, 11(3-4), 133-136.

7. Aragon, S. R. (2003). Creating social presence in online environments. New Directions for Adult and Continuing Education, 100, 57-68.

8. Bente, G., Ruggenberg, S., Kramer, N. C., \& Eschenburg, F. (2008). Avatar-mediated networking: Increasing social presence and interpersonal trust in net-based collaborations. Human Communication Research, 34(2), 287-318.

9. Biocca, F., Harms, C., \& Burgoon, J. (2003). Toward a more robust theory and measure of social presence: Review and suggested criteria. Presence: Teleoperators and Virtual Environments, 12(5), 456-480.

10. Borup, J., Graham, C. R., \& Velasquez, A. (2011). The use of asynchronous video communication to improve instructor immediacy and social presence in a blended learning environment. In A. Kitchenham (Ed.), Blended learning across disciplines: Models for implementation (p.38-57). Hershey, PA: IGI Global.

11. Borup, J., West, R. E., \& Graham, C. R. (2012). Improving online social presence through asynchronous video. The Internet and Higher Education, 15, 195-203. doi:10.1016/ j.iheduc.2011.11.001

12. Boston, W., Diaz, S. R., Gibson, A. M., Ice, P., Richardson, J., \& Swan, K. (2009). An exploration of the relationship between indicators of the community of inquiry framework and retention in online programs. Journal of Asynchronous Learning Networks, 13(3), 67-83.

13. Brower, H. (2003). On emulating classroom discussion in a distance-delivered OBHR course: Creating an online community. Academy of Management Learning \& Education, 2, 22-36.

14. Caspi, A., and I. Blau. (2008). Social presence in online discussion groups: Testing three conceptions and their relations to perceived learning. Social Psychological Education, 11(3), 323-46.

15. Cui, G., Lockee, B., \& Meng, C. (2012). Building modern online social presence: A review of social presence theory and its instructional design implications for future trends. Education and Information Technologies. doi: 10.1007/ s10639-012-9192-1.

16. D'Ambra, J., Rice, R.E., \& O'Connor, M. (1998). Computer-mediated communication and media preference: An investigation of the dimensionality of perceived task equivocality and media richness. Behaviour and Information Technology, 17(3), 164-174.

17. Delfino, M., \& Manca, S. (2007). The expression of social presence through the use of figurative language in a web based learning environment. Computers in Human Behavior, 23(5), 2190-2211.

18. Denzin N. K., \& Lincoln Y. S. (2005). The SAGE handbook of qualitative research. Thousand Oaks: Sage Publications.

19. Draus, P., Curran, M. J., \& Trempus, M. S. (2014). The influence of instructor-generated video content on student satisfaction with and engagement in asynchronous online asynchronous online classes. MERLOT Journal of Online Learning and Teaching, 10(2). Retrieved from http://jolt.merlot.org/vol10no2/draus_0614.pdf.

20. Garrett Dikkers, A., \& Whiteside, A.L. (2008, August). Using the social presence model to maximize online learning. Paper presented at the 24th Annual Conference on Distance Teaching and Learning. Madison, WI

21. Garrett Dikkers, A., Whiteside, A., \& Lewis, S. (2013). Virtual high school teacher and student reactions to the social presence model. Journal Of Interactive Online Learning, 12(3), 156-170.

22. Garrison, D.R. (1993). A cognitive constructivist view of distance education: An analysis of teaching-learning assumptions. Distance Education: An International Journal, 4(2), 199-211.

23. Garrison, D.R. (1997). Computer conferencing: The post-industrial age of distance education. Open Learning, $12(2), 3-11$.

24. Garrison, D.R. (2007). Online community of inquiry review: Social, cognitive and teaching presence issues. Journal of Asynchronous Learning Networks 11(1), 61-72.

25. Garrison, D. R., Anderson, T., \& Archer, W. (2000). Critical inquiry in a text-based environment: Computer conferencing in higher education. The Internet and Higher Education, 2(2-3), 87-105. 


\section{Issues in Information Systems \\ Volume 15, Issue I, pp. 267-276, 2014}

26. Griffiths, M. E., \& Graham, C. R. (2009). Using asynchronous video in online classes: Results from a pilot study. International Journal of Instructional Technology \& Distance Learning, 6, 65-76. Retrieved April 3, 2014 from http://itdl.org/Journal/Mar_09/article06.htm.

27. Guoqiang Cui (2013). Evaluating online social presence: An overview of social presence assessment. Journal Of Educational Technology Development \& Exchange, 6(1), 13-30.

28. Gunawardena, C.N. (1998). Designing collaborative learning environments mediated by computer conferencing: Issues and challenges in the Asian socio-cultural context. Indian Journal of Open Learning, 7(1), 101-119.

29. Gunawardena, C.N., and R. Zittle. (1996). An examination of teaching and learning processes in distance education and implications for designing instruction. In Distance Education Symposium 3: Instruction, ed. M.F. Beaudoin, 51-63. State College, PA: American Center for the Study of Distance Education.

30. Gunawardena, C. N., \& Zittle, F. J. (1997). Social presence as a predictor of satisfaction within a computermediated conferencing environment. The American Journal of Distance Education, 11(3), 8-26.

31. Hackman, M.Z., \& Walker, K.B. (1990). Instructional communication in the televised classroom: The effects of system design and teacher immediacy on student learning and satisfaction. Communication Education, 39(3), 196-206.

32. Hostetter, C., \& Busch, M. (2006). Measuring up online: The relationship between social presence and student learning satisfaction. Journal of Scholarship of Teaching and Learning, 6(2), 1.

33. Ice, P., Curtis, R., Phillips, P., \& Wells, J. (2007). Using asynchronous audio feedback to enhance teaching presence and student's sense of community. Journal of Asynchronous Learning Networks, 11, 3-25. Retrieved April 3, 2014 from http://sloanconsortium.org/publications/jaln_main.

34. Kehrwald, B.A. (2007). Social presence and learner support: Understanding learners' experiences with mediated social processes in text-based online learning environments (doctoral dissertation), University of Southern Queensland.

35. Kehrwald, B.A. (2008). Understanding social presence in text-based online learning environments. Distance Education, 29(1), 89-106.

36. Kim, J., Kwon, Y., \& Cho, D. (2011). Investigating factors that influence social presence and learning outcomes in distance higher education. Computers and Education, 57, 1512-1520.

37. Kumar, N., \& Benbasat, I. (2002). Para-social presence and communication capabilities of a web site. eService Journal, 1(3), 5-24.

38. Ladyshewsky, R. (2013). Instructor presence in online courses and student satisfaction. International Journal For The Scholarship Of Teaching \& Learning, 7(1), 1-23.

39. Liu, S. Y., Gomez, J., \& Yen, C-J. (2009). Community college online course retention and final grade: Predictability of social presence. Journal of Interactive Online Learning, 8(2), 165-182.

40. Lowenthal, P. R. (2009). The evolution and influence of social presence theory on online learning. In T. T. Kidd (Ed.), Online education and adult learning: New frontiers for teaching practices (pp. 124-139). Hershey, PA: IGI Global.

41. Lowenthal, P. R. (2012). Social presence: What is it? How do we measure it? (Unpublished doctoral dissertation). University of Colorado Denver, Denver, Colorado.

42. McLeod, P.L., Baron, R.S., \& Marti, M.W. (1997). The eyes have it: Minority influence in face-to-face and computer-mediated group discussion. Journal of Applied Psychology, 82(5), 706-718.

43. Merriam, S. B. (1998). Qualitative research and case study applications in education: Revised and expanded from case study research in education. San Francisco, CA: Jossey-Bass.

44. Murphy, E. (2004). Recognising and promoting collaboration in an online asynchronous discussion. British Journal of Educational Technology, 35(4), 421-431.

45. Peltier, J., Schibrowsky, J., \& Drago, W. (2007). The interdependence of the factors influencing the perceived quality of the online learning experience: A causal model. Journal of Marketing Education, 29, 140-153.

46. Picciano, A. (2002). Beyond student perceptions: Issues of interaction, presence, and performance in an online course. Journal of Asynchronous Learning Networks, 6(1), 21- 40.

47. Pratt, H. K. (1996). The electronic personality (Doctoral dissertation). Retrieved from ProQuest Dissertations and Theses database. (UMI No. 304283630).

48. Richardson, J.C., \& Swan, K. (2003). Examining social presence in online courses in relation to students' perceived learning and satisfaction. Journal of Asynchronous Learning Networks, 7(1). Retrieved from http://www.aln.org/publications/jaln/v7n1/pdf/v7n1_richardson.pdf.

49. Rogers, P. \& Lea, M. (2005). Social presence in distributed group environments: The role of social identity. Behavior \& Information Technology, 24(2), 151-158. 


\section{Issues in Information Systems \\ Volume 15, Issue I, pp. 267-276, 2014}

50. Rourke, L., Anderson, T., Garrison, D.R., \& Archer, W. (2001). Assessing social presence in asynchronous textbased computer conferencing. Journal of Distance Education, 14(2), 50-71.

51. Rourke, L., \& Kanuka, H. (2009). Learning in communities of inquiry: A review of the literature. Journal of Distance Education, 23(1), 19-48.

52. Shea, P., \& Bidjerano, T. (2010). Learning presence: Towards a theory of self-efficacy, self-regulation, and the development of a communities of inquiry in online and blended learning environments. Computers \& Education, 55, 1721-1731. doi:10.1016/j.compedu.2010.07.017

53. Shea, P., Li, C. S., \& Pickett, A. (2006). A study of teaching presence and student sense of learning community in fully online and web-enhanced college courses. The Internet and Higher Education, 9(3), 175-190.

54. Short, J., E. Williams, and B. Christie. (1976). The social psychology of communication. New York: John Wiley \& Sons.

55. Swan, K., \& Shih, L.F. (2005). On the nature and development of social presence in online course discussions. Journal of Asynchronous Learning Networks, 9(3), 115-136.

56. Swan, K., Richardson, J. C., Ice, P., Garrison, R. D., Cleveland-Innes, M., \& Arbaugh, J. B. (2008). Validating a measurement tool of presence in online communities of inquiry. ementor, 2(24), 1-12.

57. Tu, C.-H. (2001). How Chinese perceive social presence: An examination of interaction in online learning environment. Education Media International, 38(1), 45-60.

58. Tu, C.-H. (2002). The impacts of text-based CMC on online social presence. The Journal of Interactive Online Learning, 1(2), 1-24.

59. Tu, C.-H., \& McIsaac, M. (2002). The relationship of social presence and interaction in online classes. The American Journal of Distance Education, 16(3), 131-150.

60. Weinel, M., Bannert, M., Zumbach, J., Hoppe, H. U., \& Malzahn, N. (2011). A closer look on social presence as a causing factor in computer-mediated collaboration. Computers in Human Behavior, 27(1), 513-521. 